\title{
Intellectual Capital in Practice in the Public Sector: Developing a Conceptual Framework for the 'Third Wave'
}

\begin{abstract}
Awais Alam Khan ${ }^{1}$, Muhammad Nouman ${ }^{2}$
Abstract

Throughout the world, public sector organisations are under continuous pressure from various stakeholders for performance improvement. Public sector, just like corporate sector is also utilising intellectual capital (IC) in various ways and it is being argued that IC as a strategic resource can also help in improving the performance of this sector. However, research on intellectual capital in public sector is still very scarce, and especially, in the context of developing countries, almost non-existent.
\end{abstract}

The IC body of knowledge has evolved through various stages and currently it is moving towards the fourth stage. This paper is focussing on the third stage of 'IC in practice'. The third stage of IC research advocates the complex and idiosyncratic nature of intellectual capital and stresses on researching ' $\mathrm{C}$ in action' i.e., IC practices and managerial implications rather than measuring it. This theoretical paper aims to propose a framework to explore IC phenomenon in the knowledge intensive public sector organisations of a developing country (Pakistan). It raises the issues of the role of IC in value creation or destruction in the public sector and practices associated with intellectual capital, in such organisations which do not have explicit IC management strategies however, through their practices these organisations are managing it. It also develops a conceptual framework which proposes to study the IC practices of the public sector organisations through performative IC, social construction, and structuration lenses in order to grasp the complexity of conceptualising the IC, its particular nature, failure of generalisation of the IC grand theories, and development of IC body of knowledge. This framework focuses on understanding the phenomenon and its role in public sector organisations.

The framework contributes towards the IC in Practice perspective of IC body of knowledge in the specific context of public sector organisations in a developing country and suggests that by adopting an appropriate methodology, the practices, management, and development of IC

1 PhD Scholar and Assistant Professor at the Institute of Management Sciences, Peshawar.

Email:awais.alam@imsciences.edu.pk

2 Associate Professor, Institute of Management Sciences, Peshawar.

Email:muhammad.nouman@imsciences.edu.pk

\section{ARTICLE HISTORY}

26 Feb, 2019 Submission Received

27 Mar, 2019 First Review

11 May, 2019 Second Review

9 June, 2019 Third Review

15 Jun, 2019 Accepted 
can be better comprehended through this framework.

Keywords: Intellectual capital, public Sector, IC practices, structuration, value creation

\section{Introduction}

In the knowledge economy, the importance of intellectual capital (IC) as a unique resource and foundation of business success has been acknowledged equally by academics and practitioners (Bontis 1998; Dumay \& Rooney, 2016). IC includes all the intangibles that can be put to use to create wealth (Stewart, 1997; Kong \& Thomson, 2009) and in the knowledge economy, these intangibles are becoming more valuable for the companies as compared to the tangible assets.

Globally, corporate sector realised importance of IC in 1990s' and started to utilise IC to gain competitive advantage and it became a critical success factor for most organisations (Bontis, 1988; Tull \& Dumay, 2007; Borin \& Donato, 2015; Secundo, Dumay, Schiuma \& Dumay, 2016; Dumay \& Rooney, 2016; Tran \& Vo, 2018). The knowledge economy has also affected public sector (PS) throughout the world, resulting in changes, which are more visible in developed countries. PS organisations have become more accessible, accountable and 'company-ised', 'accounting-ised', and re-invented, to be more productive, efficient and be able to satisfy customers (Power \& Laughlin, 1994; Mouritsen, Thorbjornsen, Bukh, \& Johansen, 2004). This movement from conventional bureaucratic management style to a modernisedsystem of public management (Cabrita \&Vaz, 2006; Whyte \& Zyngier, 2014) is geared by the utilisation of IC in the PS after its successful utilisation int the corporate sector, as one of the main premises of modern public management is to adopt successful practices from corporate sector.

The IC body of knowledge has evolved over a period of time from debates regarding its introduction, to its measurement, and to its practical implications in the organisations, to developing a broader IC eco-system of communities, regions, cities or organisations (Borin \& Donato, 2015; Secundo, Lombardi, \& Dumay, 2018). However, research is still needed regarding IC praxis in different contexts (Dumay \& Garanina, 2013; Dumay, Guthrie \& Puntillo, 2015; Guthrie \& Dumay, 2015).

This theoretical paper proposes a framework to understand the role of IC in PS organisations in Pakistan, in order to evaluate the role of IC in action in the PS and evaluate the utilisation of the elements of IC in this vital sector. While, there has been a lot of research conducted in corporate sector regarding IC and its role, there is scarcity of research in the PS on this topic (Guthrie, Ricceri, \& Dumay, 2012; Guthrie \& Dumay, 2015) and research is almost non-existent in the context of Pakistan (Khan \& Jamal, 2013; Khan, 2007) where the public-sector organisations still have 
not adopted any measures for the management of their IC in explicit ways.

For this purpose, this paper is arranged into different sections. Section 2 gives review of literature; section 3 presents the research framework, section 4 discusses the justification of framework and section 5 consists of the conclusion of the paper.

\section{Literature review}

The term "intellectual capital" was first introduced by Galbraith (1969), as an ideological process to create value in organisations. Kozak (2011) points out that the conceptualisation of IC is still evolving, and there is no uniform definition accepted for identifying its sub-components and its universal conceptualisation. One of the earlier definitions of IC is proposed by Stewart (1997:x) as "packaged useful knowledge" meaning that IC is a total stock of the collective knowledge, information, technologies, skills, expertise, intellectual property, customer loyalty and team management that can be used to create value". Edvinsson (1997:366) defined IC, as "the sum of human capital and structural capital". Stewart (1997) extended IC into three parts: human capital, customer capital and structural capital. Abeysekara (2008) however,terms IC as a complex phenomenon and argues that several authors define it in different ways, while some commonalities exist, however, this diversity of definitions make it difficult to arrive at a single definition. Similarly, the literature is hazy about distinction between IC and intellectual assets (Edvinsson \& Sullivan, 1996). Resultantly, Abeysekara (2008) argues that organisations take topic of IC in an experiential and idiosyncratic way. Habersam and Piber (2003) also ascribe to the idea of difficulty of conceptualising IC in organisations and opine that there are multiple perspectives of IC in which some constitute the objective facts, but others are still based on cognitive and unconscious interpretations. Jacob and Ebrahimpur (2001) argue that understanding this complex phenomenon requires to comprehend it within the holistic perspective of an organisation's values system and cultural context. As researchers Larsen, Bukh and Mouritsen (1999, p. 16) add that, "IC is not interesting for what it is. It is interesting for its effects, for what it does and how it works" emphasising on the 'action' part of IC' and Collier (2001) states that managerial actions refer to how IC is utilised in the organisations. Therefore, it seems very difficult to find an exhaustive taxonomy for IC in order to keep the dynamic link between IC, organisation and context alive (Abeysekera, 2006; Alwert, Bornemann \& Will, 2009; Dumay, 2009).

This complexity of conceptualising IC becomes one of impediments for its acceptance and adoption as well, especially, in the public sector organisations (PSOs). No doubt, while corporate sector throughout the world has recognised the phenomenon, it still is difficult to acquaint the comparatively less developed public sector in 
a developing country with it in some significant way.

Various authors (Harrison \& Sullivan, 2000; Mar, Gray, \& Neely, 2003; Tull \& Dumay, 2007) suggest that organisations can obtain a diverse range of values from their IC such as: profit generation, improved productivity, strategic positioning, innovations, customer loyalty, efficiency and effectiveness and is associated with higher levels of organisational performance. Edvinsson and Bounfour (2004) suggest that value creation is the interaction of human and organisational capital. Green (2006) also defined and elaborated the value drivers in organisations, which are related with the IC of the organisations, for example; development of their brand, reputation, trademarks, software, research and development $(R \& D)$, patents, staff skills, strategy, process, quality, suppliers and customer relations. A growing number of academics and professionals are acknowledging that intellectual rather than physical capital is the prime factor of value creation to develop and sustain competitive advantage (Kong $\&$ Thomson, 2009). However, while most of the authors have done research on the value creation aspects of IC, Caddy (2000) argues that there are two sides of a coin and probably there are down sides of the IC as well. He terms it the intellectual liabilities (IL). He further adds that, if intellectual assets do indeed exist, then there should also exist a mirror reflection of these organisational artefacts, that is, IL or the value destruction role of intangibles. According to Stam (2009) IC is the difference between intellectual assets and intellectual liabilities and usually the intellectual liabilities are not given importance in the organisational context. If such liabilities are ignored, it can have a detrimental effect on the organisational performance. Consequently, intellectual liabilities can be viewed as the main source of competitive disadvantage and value deterioration. He proposes the assessment of risks associated with the human, structural and relational capital. Giuliani (2013) too has highlighted the lack of research on the concept of value destruction part of intangibles.

Taking this discussion forward, this paper argues that while the value creation role of IC is established in the corporate sector, however, what about the role that IC plays in the public sector? Is it creating value or is it destroying the value? Similarly, thinking from the other perspective whether the public sector creates value through IC or alternatively practices in this vital sector destroys the IC. However, this requires studying the IC practices which exist in the public sector organisations, even if such organisations are not explicitly utilising the 'terms' and 'jargons' of IC body of knowledge.

Just like corporations' quest for competitive advantage, public sector organisations too, all over the world are continuously facing pressures from society to enhance their effectiveness and quality within the limited resources (Riege $\&$ Lindsay, 2006) and have undertaken various efforts to bring improvement. Adcroft and Willis (2005) 
suggest that such efforts consist of a number of doctrines emphasising professional management, and measures of performance, with a focus on outputs and results and incorporation of management practices and systems from the private sector. However, Cong and Pandya (2003) contend that, there are enormous differences between public and corporate sector, and business practices and management philosophies cannot be transferred across the board. However, Mouritsen et al. (2004) regard IC as an attempt in change in public sector management. IC helps the public sector to become more strategic, independent and performance oriented, as it helps in internal management by learning how to develop and operate a more distributed system of management that is different from bureaucratic structures, in which human capital is empowered in decision making and the whole structure is held together by rich communication (structural capital) and a framework of (user) values. Wiig (2002; 2005) also suggest that the success and viability of society depends upon how well its public services are provided and the public sector's quality and effectiveness are influenced by different factors, such as, organisational structures, information, and experience of employees which are all the components of IC. Similarly, Sotirakou and Zeppou (2004) and Abeysekera, Jebeile, and Kamuruddin (2010) also argue that public sector modernisation cannot work without the involvement and commitment of its human capital and thus IC is the most critical and valuable asset in developing new management systems in public sector organisations. To date, IC approach has mostly been applied to business sector (Guthrie, Ricceri, \& Dumay, 2012). However, public sector organisations are also under continuous pressures to improve performance, which require more input in the form of human, structural and relational capital thus IC is assumed to play a huge role in the value creation process of this sector as well (Dumay, Guthrie, \& Puntillo, 2015; Secundo, Dumay, Schiuma, \& Passiante, 2016).

Keeping the above discussion in mind, need is felt to explore the role that IC is playing (its conceptualisation, process and role in value creation) in the public sector organisations especially in the developing countries and in such organisations in the public sector which are in the process of bringing change in their operations or which have already passed through strategic changes and are directed towards incorporating modern concepts of management in their operations.

While the previous part of literature tried to develop a conceptual build-up of relationship between the changing public sector and incorporation of IC and its elements in this changing context, in this paragraph, the development of IC research (ICR) is discussed, as it is helpful in identifying the gaps in the body of knowledge of IC and understanding the purpose of this paper. Regarding the development in the ICR, Dumay and Garanina (2013) observe that it can be classified into three different stages. These stages have been summarised in Table 1 , as well. 
Table 1: Stages of IC Development (developed from Dumay and Garanina, 2013)

\begin{tabular}{|c|c|c|c|}
\hline Stage & First Stage & Second Stage & Third Stage \\
\hline Themes & $\begin{array}{c}\text { Creating awareness } \\
\text { about IC } \\
\text { Conceptualisation } \\
\text { of IC } \\
\text { Theoretical develop- } \\
\text { ment of IC }\end{array}$ & $\begin{array}{l}\text { IC measurement, man- } \\
\text { agement and reporting } \\
\text { tools development } \\
\text { IC impact on financial } \\
\text { performance }\end{array}$ & $\begin{array}{l}\text { Critical examination } \\
\text { of IC in practice } \\
\text { How practically IC } \\
\text { works in organisations }\end{array}$ \\
\hline Time period & 1990 s & $2000 \mathrm{~s}$ & $2010 s$ \\
\hline Outcomes & IC Grand Theories & $\begin{array}{l}\text { Tools to measure, man- } \\
\text { age, report IC }\end{array}$ & $\begin{array}{c}\text { The managerial impli- } \\
\text { cations of IC in action } \\
\text { in organisations }\end{array}$ \\
\hline Contributors & $\begin{array}{l}\text { Thomas Stewart, } \\
\text { Leif Edvinsson, Karl } \\
\text { Sveiby, Goran Roos, } \\
\text { JurgeonDuam, Nick } \\
\text { Bontis, and others }\end{array}$ & $\begin{array}{l}\text { Thomas Stewart, } \\
\text { Leif Edvinsson, Karl } \\
\text { Sveiby, Roos et al., } \\
\text { Brookings, Kaplan \& } \\
\text { Norton, Baruch Lev, } \\
\text { Mouritsen et al., Neely } \\
\text { et al., Dow Chemicals } \\
\text { and others }\end{array}$ & $\begin{array}{l}\text { Mourtisen et al., } \\
\text { Guthrie, John Dumay, } \\
\text { Chiuuchi, Edvinsson, } \\
\text { Garanina, and others }\end{array}$ \\
\hline
\end{tabular}

The first stage of ICR has its roots in the 1990s and according to Petty and Guthrie (2000) helped in conceptualising and developing a "framework of intellectual capital". We can say that the focus of the first stage was to create awareness regarding the recognition of IC, and the role it can play in the attainment of the competitive advantage. This stage was more about the theoretical development of the IC body of knowledge such as, identification of the various elements of the IC.The first stage of ICR is firmly grounded in the work of practitioners in the 1980s and 1990s (Sveiby, 1997).

In second stage of ICR, approaches to IC measurement, management and reportingcame to fore (Petty \& Guthrie, 2000). During this stage, the major focus of researchers was to develop models and measures to 'manage' IC and hence, different classifications were created which helped to define and group different methods of IC evaluation (Ricceri, 2008). As Sveiby (2010) counts that during 2000-2005, more than 50 methods were created which either helped to define IC as a whole, or define different elements of IC, and the process kept its momentum onwards, as well.

A third development momentum started visible in the IC body of knowledge from 2004, and beyond evidenced in the work of various authors, which according to Guthrie et al. (2012) is distinctive in characteristics as it emphasise on the critical examination of IC in practice i.e., how IC is used and developed in the organisa- 
tions and its implications, termed as 'transformational IC, by Dumay and Garanina (2013). The development of this stage progressed with the works of Mouritsen (2006); Roslender and Stevenson, (2009); Dumay and Cuganesan (2011), stressing on the managerial desire to better understand the possible underlying relationships between their people, processes and IC (human, structural and relational capital) rather than adopting the 'grand theories' developed in stage one. So, while second stage ICR is predominately devoted to the measurement of IC and its linkage with the financial outcomes of the organisations, the, third stageof ICR focuses on the deeper managerial implications of managing IC in all types of organisations and can be classified as bottom-up research as opposed to top-down.

Nowadays, some authors (Secundo et al., 2016; Bisogno, Dumay, Rossi, \& Polcini, 2018; Secundo, Lombardi, \& Dumay, 2018) in the ICR are hinting at the initiation of a fourth stage of IC as well. This stage is being associated with the development of a grand IC eco-system which transcends beyond organisational boundaries and looks at IC from a broader lens of collective intelligence of geographical boundaries such as cities, regions, and a country or countries.

This paper proposes to work on the gaps in the ICR by exploring the role of IC in the public sector organisations in order to better understand the managerial implications associated with the phenomenon and how IC is practiced (IC praxis), managed and contribution in the value creation process in this vital sector.

\section{Framework to study IC in PSOs}

Mouritsen (2006), based on the work of Latour (1986) distinguishes ICR into two different tracks of ostensive and performative approach. This serves to highlight choices faced by researchers pursuing IC research. The ostensive definition of reality or IC in ICR takes IC as a static and standardised phenomenon having a set of fundamental properties, separate from the organisational context and the actors in an organisational setting. This view separates IC as a phenomenon from the context and views IC is a source of value creation, with the ability to measure it and is tilted towards the positivist paradigm. This approach states that IC elements are connected to value creation and organisational results in one fundamental way. The task for research is to uncover this formula. He terms this theory as IC1.

$\mathrm{He}$ also proposes an alternative theory, IC2 which is related to the performative definition of reality (Latour, 1986). In this situation the form and function of IC cannot be identified a priori. IC gains its identity by its relations to other entities and it is idiosyncratic in different situations or organisations. Thus, this view suggests that IC is based on the interaction of the actors and organisational settings and cannot 
be separated from its context. IC is not a standardised phenomenon rather it is idiosyncratic in nature owing to the context and interactivity of the actors. So, this view adopts a practice based, dynamic IC perspective.

This discussion leads to the development of propositions that while IC1 looks for the whole picture that makes IC as a phenomenon, separate from organisations, and actors, IC2 adopts an action and interactivity-based approach. While IC1 will look for fundamental relations and paths between elements of IC and further towards the performance of the firm or the capital market, IC2 will look for how actors mobilise IC elements, how the IC elements are connected and allowed to do certain things. Similarly, While IC1 will ask how IC is a stable resource that can be associated with predictable effects; IC2 will be concerned with how IC elements are mobilised and related to effects that themselves are invented in the network where IC is given meaning. This thinking is further developed by the work of Mouritsen (2006); Mouritsen and Roslender (2009); Roslender and Stevenson (2009); Dumay (2009), Guthrie et al. (2012) and Dumay and Garanina (2013) and also termed as the Third Wave of ICR.

This paper proposes adoption of a performative IC (Mouritsen, 2006) for IC research in the public sector organisations in Pakistan as a first lens. Several reasons can be given for adopting this perspective. One, IC is yet a phenomenon which is not managed/organised in the explicit context in this sector. Second, if data is not explicit or quantitatively available then perhaps the best way is to explore it in the actual context. Thirdly, there are contextual inter-sectoral and intra-sectoral differences between developing and developed countries. Therefore, this paper proposes that to study IC in our specific context, it needs to be conceptualised through the managers

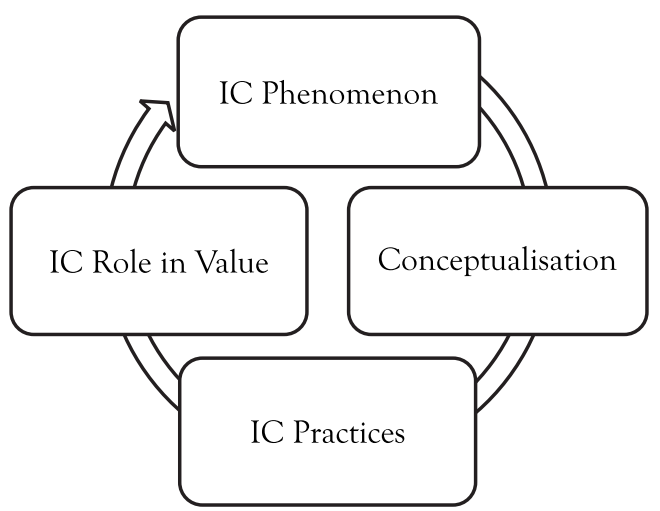

Fig 1: Studying IC in Public Sector Organisations 
(discursive, practical, and reflexive) knowledge, the practices involved need to be studied (as performed in these organisations in their context/settings) and then it can be evaluated that what role IC is playing in public sector organisations in Pakistan, figure 1 is illustrating the same.

Similarly, this paper proposes to explore this phenomenon through the various lenses in order to understand it in the mentioned specific context as given in the table 2 too.

We propose social constructionism lens as a second lens for such a research, which has its roots in interpretivism (Bryman, 2012).The phrase social construction typically refers to the paradigm that traces the origin of knowledge and meaning and the nature of reality to processes generated within human relationships. Constructionists understanding of knowledge is based on the interaction of actors and socially constructed through language, and reality as connected and known through cultural and historical contexts. Human activity is not regarded as a tangible material reality to be discovered and measured; rather it is considered to be a "text" that can be read, interpreted, deconstructed, and analysed (Tracy, 2013).

Social constructionism seeks to understand how humans make sense of their world as they act and interact with each other in meaningful ways. As such, social constructionism is concerned with the social processes that enable humans to construct their reality and to make sense of the world around them. Social constructionism does not predict human behaviour and human experiences; rather it contributes toward the understanding of the human experiences and behaviours in a specific socio-cultural context (Burr, 2003). Social constructionism is concerned with how meaning 'is socially (and variously) constructed, sustained, modified and negotiated' (Lock \& Strong, 2010).

The third lens that we propose from the social theory perspective is "Structuration Theory" (Giddens, 1984; Stones, 2005), that points towards the idea of duality of structures and views social systems (organisations) as the interaction between the structures of signification, domination, and legitimation and the agency (interaction of the agents). Following Orlikowski (2000), we propose the understanding of the recursive interactivity between people, the elements of intellectual capital, and social action. We believe such a practice orientation can better explain a practice perspective of IC rather than the ostensive perspective, on which major chunk of research has already been done in the past years. The reason for adopting this perspective is the argument of the invisibility of IC and while much has been said regarding the value creation capabilities of IC, in our opinion, the best option is to have a look at the people who are involved in practicing IC in their organisational (social) settings. So, it 
can be argued that when IC is practiced it becomes institutionalised (Giddens, 1984). This approach focuses on the 'everyday activities' of the organisations and answers to the 'how IC' phenomenon. It explains the dynamics of theoretical relations of the 'everyday activities' and their generation and operations within the contextual boundaries and over time. Of late, this lens has gained momentum in the organisational studies (Giddens, 1984; Stones, 2005; Orlikowski, 2000; Cunliffe, 2008).

These three lenses help us to understand the way intellectual capital is utilised in the organisations through the interactivity of actors, in a specific organisational context, developed over a period of time in a recurring manner, which produces a context specific structure of IC. Thus, it does not make any prior assumptions about properties and utilities of IC rather, these lenses propose to explore IC with in practice.

A traditional way of IC research mostly focuses on identifying the IC elements and measurement of IC in the organisations while our framework aims for research which is more focussed on the actual praxis and practices of IC in the organisations without assigning numbers to IC or its various elements. So, this view starts with human action and examines how it enacts emergent structures through recurrent interaction with IC. Focusing attention on how structures are constituted and reconstituted in recurrent social practices acknowledges that the performative IC may be even different from the ostensive perspective of IC.

\section{Discussion on the Justification of the Research framework}

Previous researches (Mouritsen, 2006; Mouritsen \& Roslender, 2009; Roslender \& Stevenson, 2009); Dumay, 2009; Guthrie et al., 2012; Dumay \& Garanina, 2013) critically analyse the ICR and propose the third stage of ICR which is based on the practical implications of IC. Their main premise was to study "how IC works" rather than a top-down ostensive IC framework or model to classify or measure the effects of IC in numbers or financial perspective as it provides a more detailed view of the actual implications of IC in the organisational setting.

This paper too, supports this view and therefore proposed the described framework which is not taking a priori view of the IC phenomenon but rather, is suggesting to adopting a bottom-up approach of examining the practices to theory building. When the performative bottom-up approach is used to gathering insights into the workings of IC then models describing the interaction of IC elements can be developed rather than trying to allocate abstract IC measures in an attempt to fit into a predefined framework or model. This will help in creating insights into the impact of IC praxis, which can be used to critique, selecting what worked and what did not, giving researchers and practitioners the ability to reflect on the impact to inform future 


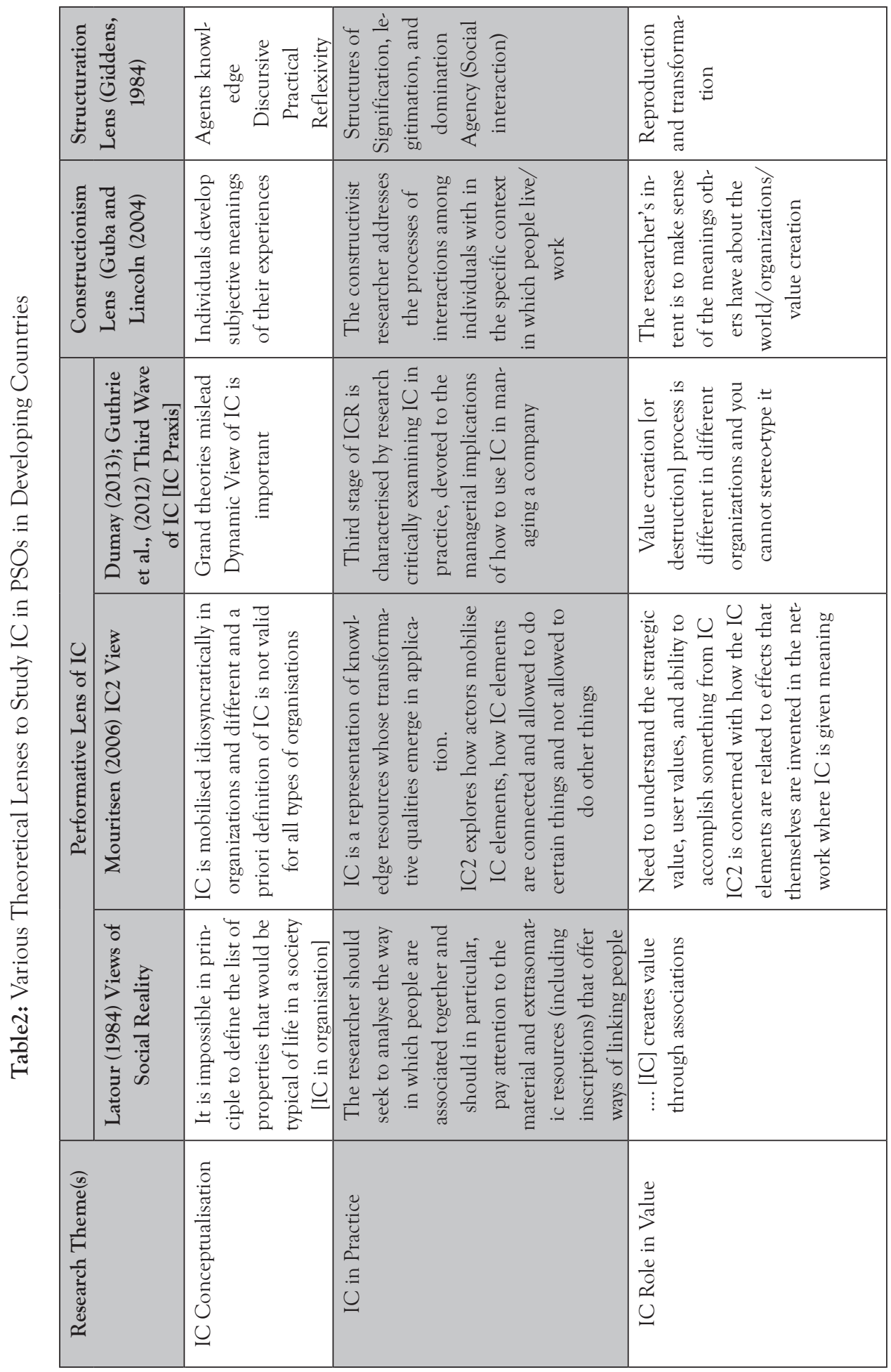


praxis. Dumay and Rooney (2011) conclude "it is possible to effectively implement IC practices without necessarily needing concrete IC measures". Thus, an "account" of IC practices can be delivered rather than IC measures. It is practice that helps researchers and practitioners to internalise what works (and what does not) inside a specific organisation rather than research that can be generalised to all organisations.

Catasus, Ersson, Grojer, and Wallentin (2007) also explored measuring and managing IC and concluded that the relationship between measurement, management and actions is not significant, however, IC mobilisation can be more useful. Their argument implies that managing effectively requires action before measuring can have any impact. Bossi, Fuertes, and Serrano (2001) point out that it is difficult to apply IC models that have been designed for the private business to the public sector, since the objectives of public sector organisations are different from the objectives of private businesses. We believe that IC in PSOs needs to be studied in the specific context rather than a measurement and management tool for intangibles. Thus, as IC researchers, we need to walk the talk by working in organisations with practitioners and managers in real time, to understand the IC praxis.

Guthrie et al., 2012 found public sector as the least researched area in the field of ICR and stressed on researching in the vital sector. Similarly, various authors, (Dumay et al., 2015; Guthrie \& Dumay, 2015) also affirmed the lack of research in the public sector. They point towards the contextual gap of just one publication from Asia/China on IC in public sector organisations, thus highlighting the contextual gap in the body of knowledge. Similarly, the major chunk of research is found to be carried out in the academia and health sector. There are several other types of public sector organisations where IC practices needs to be examined such as law enforcement agencies, emergency services etc., such research can positively contribute to the body of knowledge. Similarly, they (Dumay et al., 2015) points towards another research gap which is related with the focus of research. There is scarcity of research on 'IC in practice' in the public sector.

Our framework focuses on studying IC practices in a developing country's context and thus aims to contribute towards this important research gap. Second, we propose to study IC practices in a broader set of public sector organisations over a period of time. Third, the proposed three lenses (IC in practice, social construction, and structuration theory) have not been adopted in a research, therefore, it contributes to the IC body of knowledge.

\section{Conclusion}

So far, the discussion in various sections have identified the gaps in the IC research 
and taking into consideration the recent research work of various authors in the field of ICR (Mouritsen, 2006; Dumay, 2009; Dumay \& Garanina, 2013; Dumay, 2014; Dumay et al., 2015; Guthrie et al., 2012; Guthrie \& Dumay, 2015). This paper intends to explore the praxis of IC in PSOs in a developing country's context. Hence, it intends to add to a continued discourse about evolving approaches to ICR by communicating leading edge, third wave ICR, which develops IC theory in practice and effective IC management through praxis. This paper tried to raise the issues of IC in a context where the ICM do not exists in explicit way and therefore a constructivist approach (Guba \& Lincoln, 2004) will be required to examine it. Such research is intended to fill that gap in the body of knowledge as well as it may be useful for practitioners, specifically the managers and policy makers in the PSOs when they are dealing with the management of intellectual capital in their organisations to serve their stakeholders.

\section{References}

Abeysekera, I. (2006). The project of intellectual capital disclosure: Researching the research. Journal of Intellectual Capital, 7(1), 61-77.

Abeysekera, I. (2008). Intellectual capital accounting: Practices in a developing country. New York: Routledge

Abeysekera, I., Jebeile, S. \& Kamuruddin, K. (2010). Researching for intellectual capital management in new public sector organisations for effectiveness, efficiency, and reputation. AFAANZ Conference 2010 (1-23). Christchurch, New Zealand: AFAANZ.

Adcroft, A.,\& Willis, R. (2005). The (Un) intentional outcome of public sector performance measurement. International Journal of Public Sector Management, 18(5), 386-400.

Alwert, K., Bornemann, M., \& Will, M. (2009). Does intellectual capital reporting matter to financial analysts? Journal of Intellectual Capital, 10(3), 354-368.

Bisogno, M., Dumay, J., Manes Rossi, F., \& Tartaglia Polcini, P. (2018). Identifying future directions for IC research in education: a literature review. Journal of Intellectual Capital, 19(1), 10-33.

Bontis, N. (1998). Intellectual capital: An exploratory study that develops measures and models. Management Decision, 36 (2), 63-76.

Borin, E., \& Donato, F. (2015). Unlocking the potential of IC in Italian cultural ecosystems. Journal of Intellectual Capital, 16(2), 285-304.

Bossi, A., Fuertes, Y., Serrano, C. (2001). El capital intelectualen el sector público. Paper presented at VII Congreso del Instituto Internacional de Costos y II Congreso de la Asociación Española de Contabilidad Directiva, León, 4-6 July.

Bryman, A. (2012). Social research methods, 4th edn. New York: Oxford University Press. 
Cabrita, M. \&Vaz, J. (2006). Intellectual capital and value creation. The Electronic Journal of Knowledge Management,4 (1) 11-20.

Caddy, I. (2000). Intellectual capital: Recognizing both assets and liabilities. Journal of Intellectual Capital, 1(2), 129-146.

Catasus, B., Ersson, S., Grojer, J.-E., \&Wallentin, F. Y. (2007). What gets measured gets on indicating, mobilizig and acting. Accounting, Auditing and Accountibility Journal, 20(4), 505-521.

Collier. P. M. (2001). Valuing intellectual capacity in the police. Accounting, Auditing and Accountability Journal, 14, 437-455.

Cong, X.,\& Pandya, K. (2003). Issues of knowledge management in the public sector. Electronic Journal of Knowledge Management, 1(2), 25-33.

Cunliffe, A. L. (2008). Organization theory. London: SAGE Publications.

Dumay, J., \& Garanina, T. (2013). Intellectual capital research: A critical examination of the third stage. Journal of Intellectual Capital, 14(1), 10-25.

Dumay, J. C. (2009). Reflective discourse about intellectual capital: Research and practice. Journal of Intellectual Capital, 10(4), 489-503.

Dumay, J. (2012). Grand theories as barriers to using IC concepts. Journal of Intellectual Capital,13 (1), 4-15.

Dumay, J. (2014). 15 years of the journal of intellectual capital and counting: A manifesto for transformational IC research. Journal of Intellectual Capital, 15(1),2-37.

Dumay, J. C., \& Rooney, J. (2016). Numbers versus narrative: An examination of a controversy. Financial Accountability \& Management, 32(2), 202-231.

Dumay, J. C., \&Tull, J. A. (2007). Intellectual capital disclosure and price-sensitive Australian Stock Exchange announcements. Journal of Intellectual Capital, 8(2), 236-255

Dumay, J., Guthrie, J., \& Puntillo, P. (2015). IC and public sector: A structured literature review. Journal of Intellectual Capital, 16(2), 267-284.

Dumay, J.,\& Rooney, J. (2011). 'Measuring for managing?' An IC practice case study. Journal of Intellectual Capital, 12(3), 344-55.

Dumay, J.C. (2009). Reflective discourse about intellectual capital: Research and practice. Journal of Intellectual Capital, 10(4), 489-503.

Edvinsson, L. (1997). Intellectual capital: realizing your company's true value by finding its hidden brainpower: Harper Collins.

Edvinsson, L., \& Bounfour, A (2004). Assessing national and regional value creation. Measuring Business Excellence, 8(01), 55-61. 
Edvinsson, L., \& Sullivan, P. (1996). Developing a model for managing intellectual capital. European Management Journal, 14(4), 356-364.

Galbraith, J. K. (1969). The consequences of technology. Journal of Accountancy 127,44-56.

Giddens, A. (1984). The constitution of society: Outline of the theory of structuration. University of California Press.

Giuliani, M. (2013). Not all sunshine and roses: Discovering intellectual liabilities "in action". Journal of Intellectual Capital, 14(1), 127-144.

Green, A. (2006). Knowledge valuation: The transformation of business knowledge into intangible assets. VINE: The Journal of Information and Knowledge Management Systems, 36 (1), 27-34.

Guba, E. G., \& Lincoln, Y. S. (2004). Competing paradigms in qualitative research: Theories and issues. In S. N. Hesse-Biber \& P. Leavey (Eds.), Approaches to qualitative research: A reader on theory and practice. Oxford: Oxford University Press.

Guthrie, J. (2001). The management, measurement and the reporting of intellectual capital. Journal of Intellectual Capital,2(1), 27-41.

Guthrie, J., \& Dumay, J. (2015). New frontiers in the use of intellectual capital in the public sector. Journal of Intellectual Capital, 16(2), 258-266.

Guthrie, J., Petty, R., Ricceri, F. (2007). Intellectual capital reporting: Lessons from Hong Kong and Australia.Research Monograph,The Institute of Chartered Accountants of Scotland, Edinburgh.

Guthrie, J., Ricceri, F., \& Dumay, J. (2012). Reflections and projections: A decade of intellectual capital accounting research. The British Accounting Review, 44(2), 68-82.

Habersam, M., \& Piber, M. (2003). Exploring intellectual capital in hospitals: Two qualitative case studies in Italy and Austria. European Accounting Review, 12(4), 753-779.

Harrison, S., \& Sullivan, P. H. (2000).Profiting from intellectual capital, learning from leading companies.Journal of Intellectual Capital, 1(1), 33-46.

Jacob, M., \& Ebrahimpur, G. (2001). Experience vs. expertise - the role of implicit understandings of knowledge in determining the nature of knowledge transfer in two companies.Journal of Intellectual Capital, 2(1), 74-88.

Khan, A. A., \& Jamal, W. (2013). Intellectual capital: perception of public and private sector knowledge-based organizations in Pakistan. Business and Economic Review, 5(1), 29-52.

Khan, A. A. (2007). Intellectual capital in the public sector of Pakistan. MSc Dissertation. Glasgow Caledonian University, Glasgow

Kong, E., \& Thomson, S. B. (2009). An intellectual capital perspective of human resource strategies and practices. Knowledge Management Research \& Practice, 7, 356-364. 
Kozak, M. (2011). Strategic approach to intellectual capital development in regions. International Journal of Learning and Intellectual Capital, 8(1), 76-93

Larsen, H. T., Bukh, P. N., \& Mouritsen, J. (1999). Intellectual capital statements and knowledge management: Measuring, reporting, acting. Australian Accounting Review, 9(3),15-26.

Latour, B. (1986). The powers of association.In Law, J. (Eds), Power, actions and belief: a new sociology of knowledge. (pp. 264-280). London: Routledge and Kegan Paul.

Lock, A., \& Strong, T. (2010). Social constructionism: Sources and stirrings in theory and practice. Cambridge University Press.

Marr, B., Gray, D., \& Neely, A. (2003). Why do firms measure their intellectual capital. Journal of Intellectual Capital, 4(4), 441-464.

Mouritsen, J. (2006). Problematising intellectual capital research: Ostensive versus performative IC. Accounting, Auditing \& Accountability Journal, 19(6), 820-841.

Mouritsen, J., \& Roslender, R. (2009). Critical intellectual capital. Critical Perspectives on Accounting, 20(7), 801-803.

Mouritsen, J., Thorbjornsen, S., Bukh, P.N., and Johansen, M.R. (2005). Intellectual capital and the discourses of love and entrepreneurship in new public management. Financial Accountability \& Management, 21(3),279-290

Mouritsen, J., Thorbjornsen, S., Bukh, P.N., \& Johansen, M.R. (2004). Intellectual capital and new public management: Re-inventing enterprise. The Learning Organisation, 11(4/5),380-392.

Orlikowski, W. J. (2000). Using technology and constituting structures: A practice lens for studying technology in organizations. Organization Science, 11(4), 404-428.

Petty, R., \& Guthrie, J. (2000). Intellectual capital literature review. Journal of Intellectual Capital, $1(2), 155-76$

Power, M., \& Laughlin, R. (1994). Critical theory and accounting.In Alvesson, M. and Willmott, H. (Eds), Critical Management Studies. (pp. 113-135). London: SAGE.

Ricceri, F. (2008). Intellectual Capital and knowledge management: Strategic management of knowledge resources. New York: Routledge.

Riege, A.,\& Lindsay, N (2006). Knowledge management in the public sector: Stakeholder partnership in the public policy. Development. Journal of Knowledge Management,10(3),24-39.

Roos, G., \& Roos, J. (1997). Measuring your company's intellectual performance. Long Range Planning, 30(3), 413-26.

Roslender, R., Stevenson, J. (2009). Accounting for people: A real step forward or more a case of wishing and hoping? Critical Perspectives on Accounting, 20(7), 855-69. 
Secundo, G., Dumay, J., Schiuma, G., \& Passiante, G. (2016). Managing intellectual capital through a collective intelligence approach: An integrated framework for universities. Journal of Intellectual Capital, 17(2), 298-319.

Secundo, G., Lombardi, R., \& Dumay, J. (2018). Intellectual capital in education. Journal of Intellectual Capital, 19(1), 2-9.

Sotirakou, T., \& Zeppou, M. (2004). The "MATE" model: a strategic knowledge management technique on the chessboard of public-sector modernization. Management Decision, 42(1), 69-88.

Stam, C. D. (2009). Intellectual liabilities: Lessons from the decline and fall of the Roman Empire. VINE: The Journal of Information and Knowledge Management Systems, 39(1), 92-104.

Stewart, T. A. (1997). Intellectual capital: The new wealth of organizations. Naperville, USA: Nicholas Brealey Publishing Limited.

Stones, R., (2005). Structuration theory. Basingstoke: Palgrave-Macmillan.

Sveiby, K. E. (1997). The new organisational wealth: Managing \& measuring knowledge-based assets. San Francisco: Berrett-Koehler Publishers.

Sveiby, K.E. (2010). Methods for measuring intangible assets. Available online at: http://www.sveiby. com/articles/IntangibleMethods.htm

Tracy, S. J. (2013). Qualitative research methods. UK: Wiley-Blackwell.

Tran, D. B., \& Vo, D. H. (2018). Should bankers be concerned with Intellectual capital? A study of the Thai banking sector. Journal of Intellectual Capital, 19(5), 897-914

Tull, J.A.,\& Dumay, J.C., (2007). Does intellectual capital make a difference? A critical case study application of structuration theory. The Electronic Journal of Knowledge Management, 5(4), 515-526.

Wall, A. (2005). The measurement and management of intellectual capital in public sector. Public Management Review, 7(2), 289-303.

Whyte, M., \& Zyngier, S. (2014). Applied Intellectual Capital Management Experiences from an Australian public sector trial of the Danish Intellectual Capital Statement. Journal of Intellectual Capital, 15(2), 227-248.

Wiig, K. M. (2002). Knowledge management in public administration. Journal of Knowledge Management, 6(3), 24-239. 
